\title{
ПРАВОВІ ТА ОРГАНІЗАЦІЙНІ ФОРМИ ЗАБЕЗПЕЧЕННЯ ГРОМАДСЬКОЇ БЕЗПЕКИ В УКРАЇНІ
}

\author{
СВДОКІМЕНКО Сергій Анатолійович - кандидат юридичних наук, доцент \\ кафедри кримінально-правових дисциплін та адміністративного права ТОВ \\ «Харківський університет»
}

ORCID: 0000-0003-4700-9777

КОВАЛЕНКО Анатолій Анатолійович - доктор юридичних наук, доцент, професор кафедри публічно-правових дисциплін Київського міжнародного університету

ORCID: 0000-0003-3805-0989

DOI 10.32782/NP.2021.3.5

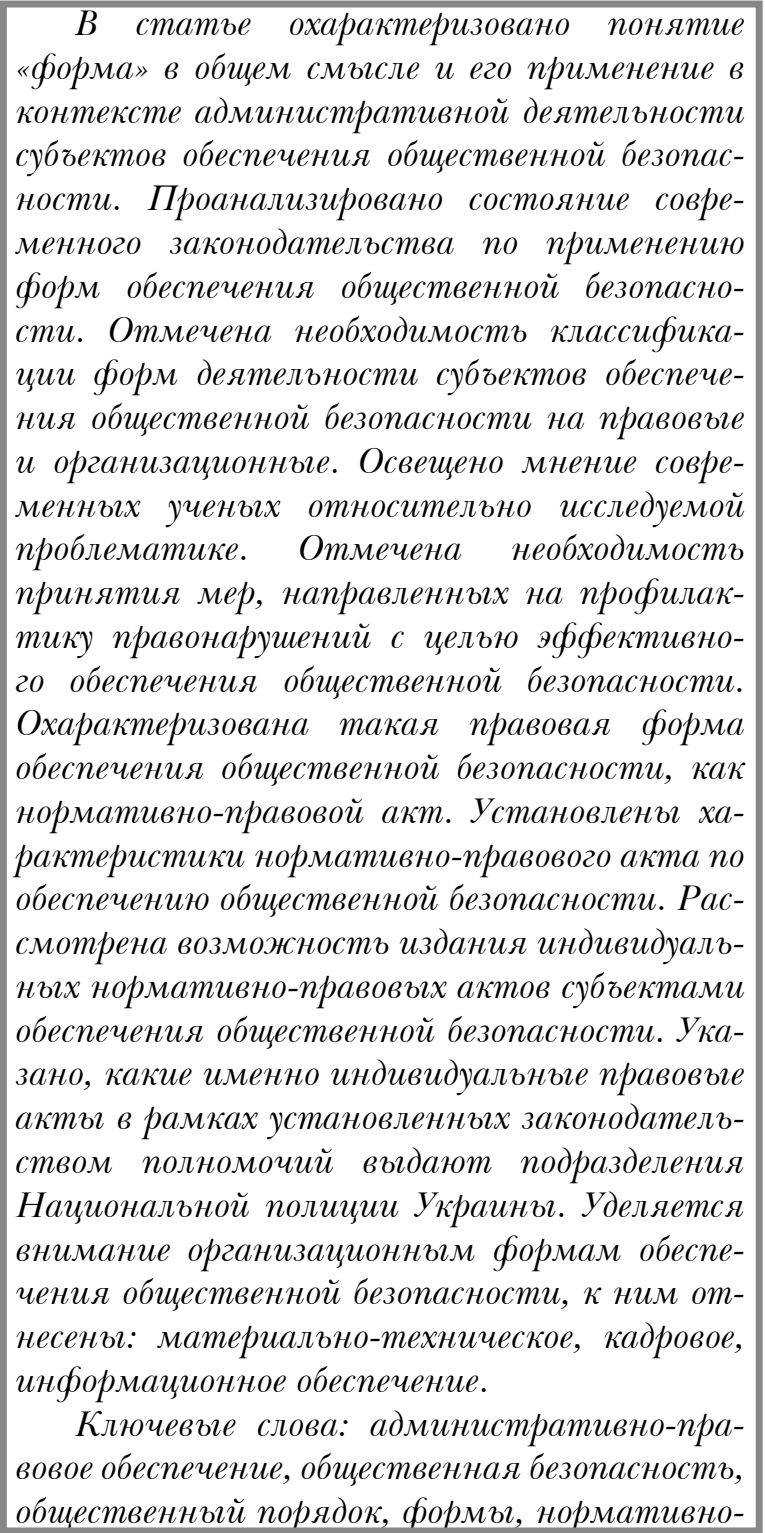

правовой акт, материальное обеспечение, кадровое обеспечение, информачионное обеспечение.

\section{Постановка проблеми}

Забезпечення громадської безпеки в Україні покладається на значну кількість державних органів та організацій. Слід приймати до уваги той факт, що, крім державних органів до вказаної діяльності залучаються приватні суб'єкти забезпечення громадської безпеки, а також громадськість. Виходячи з цього, форми забезпечення громадської безпеки є досить широким поняттям і їх застосування визначається колом повноважень суб'єкта, який їх застосовує. Тому встановлення проблемних питань, що стосуються форм забезпечення громадської безпеки, є важливим для удосконалення діяльності державних і недержавних органів та організацій, залучених до вказаної сфери.

Аналіз останніх досліджень і публікацій

Бандурка О. О. дослідив організаційні форми, спрямовані на забезпечення належного й ефективного функціонування органів державної влади та посадових осіб. Васильєв А. В. надав загальне бачення змісту поняття «форма». Ільницький О. М. надав власне визначення поняттю «адміністративно-правового забезпечення». Поняття «форми управлінської діяльності» досліджено В. Б. Авер'яновим, О. Ф. Андрійко, Ю. П. Битяком, І. П. Голосніченко, Р. А. Калюжним. Гусаров С. М. охарактеризував форму держав- 
ного управління безпекою дорожнього руху. Панова О. О. визначила основні форми адміністративної діяльності щодо забезпечення публічної безпеки. Железняк Н. В. надав своє бачення правових форм діяльності суб'єктів державної влади. Галунька В. В. визначив,що представляє собою нормативно-правовий акт у вузькому та широкому розумінні. Кравченко В. В. і Пітцик М. В. дослідили акти місцевого самоврядування, встановили їх характеристику.

\section{Не вирішені раніше частини загальної проблеми}

У законодавстві відсутнє чітке розмежування, а також тлумачення (визначення) форми забезпечення громадської безпеки. Вони вживаються в якості способів, напрямків, шляхів здійснення державними органами, організаціями, приватними юридичними і фізичними особами, громадянами дій та заходів, спрямованих на забезпечення громадської безпеки у рамках наданих їм повноважень, прав та обов'язків. Вважаємо за необхідне дослідити форми забезпечення громадської безпеки для їх чіткого розуміння в теорії та в практичній діяльності суб'єктів забезпечення громадської безпеки.

Таким чином, метою дослідження є характеристика основних форм забезпечення громадської безпеки, встановлення проблемних питань у вказаній сфері, надання пропозицій для їх вирішення.

\section{Викдад основного матеріалу}

Якщо звернутися до витоків визначення поняття «форма», то у філософії вона виражає зміст явища, предмета. Форма виражає зміст як його організацію, оскільки немає безформного змісту, як і немає безформної речі. Форма не існує сама по собі. Вона позбавлена будь-якої цінності, якщо не є формою змісту. Тому не можна погодитися з тими, хто відриває форму від змісту і наділяє ії самостійним існуванням [1, с. 117]. Васильєв А. С., вважає, що «термін «форма» тлумачиться як: 1) обриси, контури, зовнішні межі предмета, що визначають його зовнішній вигляд; 2) спосіб існування змісту, його внутрішня структура, організація і зовнішній вираз; 3) пристрій, шаблон, за допомогою якого чому-небудь надають певних обрисів, якогось вигляду;4) видимість, зовнішній бік чого-небудь, що не відображає суті справи [2, с. 97].

у науці адміністративного права під формою управлінської діяльності розуміються способи зовнішнього вираження ії змісту, а також зазначається, що державне управління виявляється в конкретних діях і взаємозв'язках органів і посадових осіб, завдяки яким управлінська діяльність набуває певних форм [3, с. 15]. Битяк Ю.П. уточнює, що функції управління розкривають основні напрями цілеспрямованого впливу суб'єктів управління на об'єкти управління, а форми управління - це шляхи здійснення такого цілеспрямованого впливу, тобто форми управління показують, як практично здійснюється управлінська діяльність [4, с. 303].

Що стосується конкретних форм забезпечення громадської безпеки, то С. М. Гусаров форму державного управління безпекою дорожнього руху встановив як правові та неправові конкретні дії уповноважених органів та їх посадових осіб, які здійснюються з метою створення сприятливих умов для реалізації суб'єктивних та спеціальних прав (відповідно право переміщення, право управління транспортним засобом), для запобігання, припинення їхніх порушень і поновлення порушеного права [5, с. 92].

Панова О. О. під формами адміністративної діяльності щодо забезпечення публічної безпеки пропонує розуміти комплекс дій, які здійснюються в межах закону та закріплених за суб'єктами забезпечення публічної безпеки повноважень та направлені на досягнення певної мети - ефективного, оптимального та достатнього забезпечення публічної безпеки шляхом попередження, припинення та подолання наслідків негативного впливу на сферу адміністративно-правових відносин у сфері публічної безпеки та створення необхідних та достатніх умов для розвитку та вдосконалення зазначеної сфери [6, с. 253].

Статтею 6 Закону України «Про участь громадян в охороні громадського порядку і державного кордону» [7] встановлено форми та методи участі громадян в охороні громадського порядку. Зокрема, у вказаній статті зазначено, що громадські формування з охорони 


\section{Адміністративне право}

громадського порядку і державного кордону проводять свою діяльність під контролем органів внутрішніх справ, підрозділів Державної прикордонної служби України шляхом:1) спільного з працівниками органів внутрішніх справ, прикордонниками патрулювання; 2) проведення разом 3 прикордонниками огляду на маршрутах можливого руху порушників державного кордону, місць їх укриття, транспортних засобів, суміжної з державним кордоном місцевості 3 метою встановлення причин та умов перебування невідомих осіб; 3) участі у заходах правоохоронних органів, спрямованих на боротьбу з окремими видами правопорушень.

У законодавстві відсутне чітке розмежування, а також тлумачення (визначення) форми забезпечення громадської безпеки. Вони вживаються в якості способів, напрямків, шляхів здійснення державними органами, організаціями, приватними юридичними і фізичними особами, громадянами дій та заходів, спрямованих на забезпечення громадської безпеки у рамках наданих їм повноважень, прав та обов'язків.

Підтримуємо точку зору О. О. Панової щодо розподілу форм забезпечення громадської безпеки на правові та організаційні. При цьому правові форми прямо передбачають настання юридичних наслідків (встановлюють юридичну відповідальність за конкретні дії), організаційні ж форми хоча не передбачають настання юридичних наслідків, проте мають не менш важливе значення для побудови якісної системи забезпечення громадської безпеки. Організаційні форми відображають сутність методів і засобів, що використовується суб'єктами забезпечення громадської безпеки в процесі виконання ними обов'язків. За допомогою організаційних форм забезпечення громадської безпеки стає можливим прорахувати необхідні матеріальні, кадрові, інформаційні ресурси тощо, необхідні для забезпечення громадської безпеки на певній території за конкретних обставин.

Железняк Н. В. вказав, що «правові форми становлять діяльність, яка пов'язана 3 виконанням юридично значимих дій у чітко встановленому законом порядку. Вони визначаються природою суб'єкта державної влади та його компетенцією у сфері здійснен- ня державно-владних повноважень» [8, с. 34]. Зупинимось на такій правовій формі забезпечення громадської безпеки, як нормативно-правовий акт. У Сучасній правовій енциклопедії за редакцією О. В. Зайчука встановлено, що акт нормативний - офіційний письмовий документ, який приймається уповноваженим органом, встановлює, змінюе або скасовує норми права. Акт підзаконний офіційний документ, прийнятий компетентним органом державної влади чи уповноваженим державою іншим суб'єктом на підставі закону і у порядку його виконання [9, с. 20, 10, с. 27]. Завдяки виданню нормативно-правових актів стає можливим вплинути на стан забезпечення громадської безпеки на території всієї держави, адже саме нормативний акт містить у собі загальні принципи, значимі для держави засади, що є важливими для забезпечення громадського порядку і безпеки. Такі акти мають вплив як на конкретну особу (передбачають настання юридичної відповідальності за вчинення правопорушень), так і розповсюджуються на групи осіб, державні, недержавні органи, організації тощо. Якщо говорити про розуміння нормативноправового акту як правової категорії, то для цього слід прослідкувати його визначення у законодавстві, а також бачення сучасних вітчизняних учених щодо вказаного питання. Так, наказом Міністерства юстиції України від 12.04.2005 р. № 34/5 «Про вдосконалення порядку державної реєстрації нормативноправових актів у Міністерстві юстиції України та скасування рішення про державну реєстрацію нормативно-правових актів» [10] встановлено, що «нормативно-правовий акт - офіційний документ, прийнятий уповноваженим на це суб'єктом нормотворення у визначеній законом формі та порядку, який встановлює норми права для неозначеного кола осіб і розрахований на неодноразове застосування»; У Кодексі адміністративного судочинства України від 06.07.2005 р.№ 2747-IV зазначено, що «нормативно-правовий акт - акт управління (рішення) суб'єкта владних повноважень, який встановлює, змінює, припиняє (скасовує) загальні правила регулювання однотипних відносин і який розрахований на довгострокове та неодноразове застосування» [11]. 
Стосовно бачення нормативно-правового акта сучасними вченими, то досить вдалими 6 висновки В. В. Галунька, який зазначив, що поняття нормативно-правового акта можна розглядати в широкому та вузькому значеннях. У першому випадку це письмовий документ компетентного суб'єкта владних повноважень, який містить формально обов'язкове правило поведінки загального характеру [12, с. 60].

Константий О. В. зазначив, що у вузькому сенсі під нормативно- правовим актом в управлінській діяльності органів влади слід розуміти правові акти, які: безпосередньо виражають регулятивну функцію адміністративного права, містять правила поведінки, що регулюють державно-управлінські відносини; розраховані на тривале (неодноразове) застосування, не визначають конкретного (персоніфікованого) адресата; є проявом реалізації правотворчих функцій органів виконавчої влади (є результатом реалізації компетенції відповідного органу державної влади), найбільш поширеною формою встановлення і перебування адміністративно-правових норм, за рахунок яких вирішуються найбільш важливі, принципові управлінські проблеми [13, c., c. 28, 29].

Крім нормативно-правових актів, суб'єкти забезпечення громадської безпеки можуть видавати й індивідуальні акти, що характеризуються індивідуальною конкретною спрямованістю. Органи та підрозділи Національної поліції України відповідно до Закону України «Про Національну поліцію» та Кодексу України про адміністративні правопорушення можуть приймати такі індивідуальні акти:

1. Правовстановлюючого характеру:

- протокол про адміністративне правопорушення;

- постанова про адміністративне правопорушення;

- протоколи особистого огляду, огляду речей;

- протоколи вилучення речей і документів тощо.

2. Організаційно-регулятивного характеpy:

- наказ про прийняття на службу до лав органів Національної поліції України;

- наказ про переведення, відрядження, звільнення тощо; -наказ про накладення, зняття чи припинення дисциплінарного стягнення, інші офіційні документи, які регламентують організаційну діяльність поліції [6, с. 265].

Індивідуальні акти правовстановлюючого характеру спрямовані саме на забезпечення законності і дотримання нормативно-правових актів загального значення, адже завдяки застосуванню індивідуальних актів стає можливим вплив на антисоціальну поведінку конкретних осіб, притягнення до відповідальності у разі вчинення правопорушень. У такому випадку індивідуальні акти мають більш процесуальний характер і прямо встановлюють наслідки невиконання законів та підзаконних нормативно-правових актів.

Крім правових форм забезпечення громадської безпеки, вчені виділяють організаційну, яка потрібна для створення умов 3 метою забезпечення виконання правозастосовних актів, що регламентують діяльність суб'єктів забезпечення громадської безпеки у сфері охорони особистих прав і свобод. Виховна форма допомагає створити необхідні умови для підвищення рівня правосвідомості як громадян, а також суб'єктів забезпечення громадської безпеки [14, с. 16]. Вважаємо, що доцільним буде включити виховні заходи до організаційної форми забезпечення громадської безпеки.

До організаційних форм забезпечення громадської безпеки, на нашу думку, слід віднести: матеріально-технічне, кадрове, інформаційне, також можна виділити правове виховання населення, а також суб'єктів забезпечення громадської безпеки, що є дуже важливим у сучасних умовах розбудови демократичної держави.

Бандурка О. О. стосовно вказаного питання слушно заявив, що організаційні форми, «спрямовані на забезпечення належного й ефективного функціонування органів державної влади та посадових осіб, які здійснюють управлінську діяльність, за часом настання можуть або передувати, або наставати після реалізації правових форм державного управління. До неправових форм державного управління відносять різноманітні організаційні заходи, а також матеріально-технічні операції, що носять допоміжний характер, призначені обслуговувати всі інші форми 


\section{Адміністративне право}

управлінської діяльності й необхідні для одноразового врегулювання управлінських відносин» [15, с. 308]. Панова О. О. зауважила, що «організаційна форма, яка виникає на основі правової або з метою іï реалізації, не завжди має однаковий вигляд ії втілення, а наслідки, які виникають від ії впровадження, залежать тільки від мотивів та завдань, які стояли перед правовою формою та зазнали певного організаційного впливу» [6, с. 298].

Учена сформулювала основні ознаки організаційних форм забезпечення громадської безпеки: «застосування організаційних форм забезпечення публічної безпеки в Україні має двоєдину будову, а саме: по-перше, може бути передумовою виникнення правової форми, по-друге, може бути їі наслідком; їх застосування не здійснює прямий вплив на права, свободи та законні інтереси людини і громадянина, а виключно забезпечує організаційну складову адміністративно-правових відносин у сфері публічної безпеки; застосовуються на основі повноважень суб'єктів забезпечення публічної безпеки, тільки в межах їх компетенційної складової та з урахуванням ситуації (оперативної обстановки), що склалась; створюють умови для виконання суб'єктами забезпечення публічної безпеки покладених на них завдань; їх застосування не призводить до настання юридично значущих наслідків; у разі неправильного або некоректного використання організаційної форми діяльність суб'єкта забезпечення публічної безпеки може бути визнана неправомірною» [6, с. 300].

\section{Висновки}

Враховуючи вищевказане, зробимо висновок, що правовими формами забезпечення громадської безпеки $\epsilon$ встановлена законодавством можливість суб'єктів забезпечення громадської безпеки застосовувати визначені законом заходи і засоби впливу у рамках наданих повноважень для ефективного забезпечення громадського порядку і безпеки. При цьому правові форми забезпечення громадської безпеки мають нормативний (загальнообов'язковий) та індивідуальний характер, тобто індивідуальну спрямованість (поширюються на конкретних осіб, коло осіб, територію тощо). Крім того, діяльність усієї системи забезпечення громадської безпеки неможливо уявити без використання організаційних форм. Саме вони формують внутрішню та зовнішню взаємодію державних органів та організацій, приватних суб'єктів забезпечення громадської безпеки, а також громадськості. Ефективність функціонування кожного суб'єкта забезпечення громадської безпосередньо залежить від організації матеріального, технічного, інформаційного, кадрового забезпечення тощо.

\section{Мiтература:}

1. Щерба С. П., Заглада О. А. Філософія : підр. 5-те вид. Київ : Кондор, 2011. С. 117.

2. Васильев А. С. Административное право Украины : учебник. Х. : Одиссей, 2001.

3. Адміністративне право України. Академічний курс : підручник: у 2 т. / В. Б. Авер'янов, О. Ф. Андрійко, Ю. П. Битяк, I. П. Голосніченко, Р. А. Калюжний та ін._; відп. ред. В. Б. Авер'янов. Е. К. : Юрид. думка, 2004. T. 1. 584 c.

4. Адміністративне право України : підручник / Ю. П. Битяк, В. М. Гаращук, О. В. Дяченко та ін._; за ред. Ю. П. Битяка. К. : Юрінком Інтер, 2005. 544 с

5. Гусаров С. М.Адміністративно-правові засади управлінської діяльності Державної автомобільної інспекції України щодо забезпечення безпеки дорожнього руху: дис. кандидата юрид. наук : спец. 12.00.07 / Гусаров Сергій Миколайович. Х., 2002.

6. Панова О. О. Забезпечення публічної безпеки в Україні: адміністративно-правовий аспект : монографія. - Харків : Панов. 2018 $510 \mathrm{c}$.

7. Про участь громадян в охороні громадського порядку і державного кордону: закон України від 22 червня 2000 року № 1835III [Електронний ресурс]. - Режим доступу: https://zakon.rada.gov.ua/laws/show/183514\#Text

8. Железняк Н. В. Нормотворча діяльність як форма реалізації державної правової політики: теоретичні та практичні проблеми. Наукові записки. 2004. Т. 26. Юридичні науки

9. Сучасна правова енциклопедія / за заг. ред. О. В. Зайчука; Ін-т законодавства Верховної Ради України. К. : Юрінком Інтер, 2010.; 


\section{АНОТАЦІЯ}

у статті надано характеристику поняттю «Форми» в загальному значенні та його застосування в контексті адміністративной діяльності суб'єктів забезпечення громадсъкої безпеки. Проаналізовано стан сучасного законодавства щодо застосування борм забезпечення громадської безпеки. Зазначено про необхідність класифікаиій борм діяльності суб'єктів забезпечення громадсъкої безпеки на правові та організаційні. Висвітлено думки сучасних учених стосовно досліджуваної проблематики. Наголошено на необхідності застосування заходів, спрямованих на профілактику правопорушень з метою ефективного забезпечення громадсъкої безпеки. Надано характеристику такій правовій бормі забезпечення громадської безпеки, як нормативно правовий акт. Встановлено ознаки нормативно-правового акта із забезпечення громадсъкої безпеки. Розглянуто можливість видання індивідуальних нормативно-правових актів суб'єктами забезпечення громадсъкой безпеки. Зазначено, які саме індивідуальні правові акти в межах визначених законом повноважень видають підрозділи Начіональної полічиї Украӥни. Приділяеться увага організачійним бормам забезпечення громадської безпеки, до нъого віднесено: матеріально-технічне, кадрове, інбормачійне забезпечення.

Ключові слова: громадсъка безпека, громадсъкий порядок, борми, нормативно-правовий акт, матеріальне забезпечення, кадрове забезпечення, інформачійне забезпечення, адміністративно-правове забезпечення.

10. Про вдосконалення порядку державної реєстрації нормативно-правових актів у Міністерстві юстиції України та скасування рішення про державну реєстрацію нормативно-правових актів: наказ Міністерства юстиції України від 12.04.2005 р. № 34/5 URL: https://zakon.rada.gov.ua/laws/show/z0381-05/ ed20190408\#n55

11. Кодекс адміністративного судочинства України : Закон України від 06.07.2005 № 2747-IV. URL: https://zakon.rada.gov.ua/ laws/ show/2747-15

12. Адміністративне право України. Т. 1: Загальне адміністративне право : навч. посіб. / В. В. Галунько, В. І. Курило, С. О. Короєд, та ін; за ред. проф. В. В. Галунька. Херсон : Грінь Д. С., 2015. C. 60
13. Константий О. В. Джерела адміністративного права України : моногр. Київ : Укр. агентство інформ. та друку «Рада», 2005. С. 28-29

14. Гіда Є. О. Загальнолюдські стандарти прав людини і забезпечення їх реалізації в діяльності міліції : автореф. дис. на здобуття наук. ступеня канд. юрид. наук : 12.00.01 / С. О. Гіда ; Інститут держави і права ім. В. М. Корецького НАН України. - К., 2000. $-16 \mathrm{c}$.

15. Адміністративне право України. Загальна частина. Академічний курс : підруч. / за заг. ред. акад. НАПрН України О. М. Бандурки. Харків : Золота миля, 2011.-С. 308.

\section{LEGAL AND ORGANIZATIONAL FORMS OF ENSURING PUBLIC SAFETY IN UKRAINE}

The author of the article has provided characteristics of the concept of "forms" in the general sense and its application in the context of administrative activities of the subjects of ensuring public safety. The state of current legislation on the application of the forms of ensuring public safety has been analyzed. It has been noted about the need to classify the forms of activity of the subjects of ensuring public security into legal and organizational. The opinions of modern scholars on the researched problems have been highlighted. The emphasis has been placed on the need to take measures aimed at crime prevention in order to effectively ensure public safety. The author has provided characteristics of such legal form of ensuring public safety as a normative and legal act. The features of the normative and legal act on ensuring public safety have been established. The possibility of issuing individual normative and legal acts by the subjects of ensuring public safety has been considered. The author has indicated those individual legal acts, which are issued by the units of the National Police of Ukraine within the powers defined by law. Particular attention has been paid to organizational forms of ensuring public safety, which include: logistical, personnel, information support.

Key words: public safety, public order, forms, regulatory act, tangible security, staffing, information support, administrative and legal provision. 